2012

\title{
A Framework to Localize International Business to Business Web Sites
}

\author{
Nitish Singh \\ Saint Louis University \\ Jieun Park \\ Cleveland State University, j.park16@csuohio.edu \\ Morris Kalliny \\ Saint Louis University
}

Follow this and additional works at: https://engagedscholarship.csuohio.edu/bus_facpub

Part of the International Business Commons

How does access to this work benefit you? Let us know!

Publisher's Statement

(C) 2012 by the Association for Computing Machinery, Inc. (ACM). This is the author's version of the work. It is posted here by permission of ACM for your personal use. Not for redistribution.

The definitive version was published in The Data Base for Advances in Information Systems, 44, 1 (2012), http://doi.acm.org/10.1145/2436239.2436243

\section{Original Published Citation}

Singh, N., Park, J., Kalliny, M. (2012). A Framework to Localize International Business to Business Web Sites. The Data Base for Advances in Information Systems, 44(1), pp. 56-77.

This Article is brought to you for free and open access by the Monte Ahuja College of Business at EngagedScholarship@CSU. It has been accepted for inclusion in Business Faculty Publications by an authorized administrator of EngagedScholarship@CSU. For more information, please contact library.es@csuohio.edu. 


\section{A Framework to Localize International Business to Business Web Sites}

\author{
Nitish Singh \\ Saint Louis University \\ Jieun Park \\ Cleveland State University
}

Morris Kalliny

Saint Louis University

\begin{abstract}
The $m$ ain pu rpose of this study $i$ s to propose and apply an analytical framework to help B2B marketers assess and develop web sites that are localized not only for th e B2B $m$ arketplace $b$ ut also for international markets. This study deals with an area that has not re ceived $m$ uch attention in academ ic research as $p$ revious studies $h$ ave mainly focused on $B 2 C$ we $b$ sites. The study focuses on $B 2 B$ web sites and provides a fram ework to assess web site localization. A content a nalysis of Am erican and Korean web sites wa s con ducted to analyze th $e$ proposed fra mework. The ove rall resul ts sh ow that U.S. com panies have $n$ ot accom plished a high degree of lo calization for B2B markets. The stud $y$ results in dicate that $m$ ost U.S. com panies focu $s$ primarily on the tran slation of web conte nt from English to Korean to create web sites. While it is true that globalization has brought us closer than ever to Mcluhan's (1 964) ide a of a glo bal village, $m$ ajor differences across countries and regions exist and play a significant role in how consumers react to web site $d$ esigns an $d$ co ntent. $T$ herefore, thi $s$ framework is vital to business se eking consum ers globally. Using this fram ework should allow businesses to locali ze $t$ heir $B 2 B w$ eb sit es and included key a reas $t$ hat app eal to local consumers. The stud y con cludes by provi ding marketers insights into fa ctors that ca $n$ hel $p$ them better localize their international B2B web sites.
\end{abstract}

Keywords: localization, Cultural customization, web site localization, South Korea, B2B e-commerce

ACM Categories: H.5.2 Information Interfaces and Presentation

\section{Introduction}

Globalization enabled by technological advances has opened the world for international trade more than any other time in history. Consumers and businesses are now can engaged in international trade via the web without ever having to leave their country or even home to obtain goods sold thousands of miles away. This has been so true for business to business activity which is the focus of this paper.

Today business-to-business (B2B) e-commerce accounts for the majority of e-commerce activity worldwide. US census E-Stats Report estimated that B2B e-commerce accounted for almost 93 percent of the total e-commerce conducted in 2007. Manufacturers lead all industry sectors in terms of ecommerce activity in 2007 with almost $\$ 1,856$ billion 
or 35 percent in total shipments (E-Stats Report, 2009). Merchant wholesalers, including Manufacturing Sales Branches and Offices (MSBOs), were ranked the second in e-commerce activity accounting for 21.2 percent of total sales $\$ 1,226$ billion (E-Stats Report, 2009). While Retail ecommerce only accounted for $\$ 127$ billion in ecommerce sales in 2007, IDC estimates that in 2009 IT and e-marketplace spending was around $\$ 496.7$ billion in the USA and $\$ 1.3$ trillion globally (Ratnasingam, 2007). These numbers clearly show the importance of B2B e-commerce in the overall ecommerce arena. The main purpose of this study is to propose and apply a framework to help B2B marketers assess and develop web sites that are localized not only for the B2B marketplace but also for international markets.

Globalization has significantly increased our awareness of the cultural differences between various countries and regions in the world. While globalization is helping decrease some of these differences, they continue to exist and play a significant role in how business activities are done around the world. To have a global presence, companies are not only becoming more international physically but also electronically by globalizing their e-business activities. Cultural differences extend themselves to this e-commerce environment and play a crucial role in determining e-commerce success (e.g. Singh and Pereira, 2005). Therefore, when businesses globalize their e-business, it is important to recognize that language, cultural expectations and trust play a crucial role in enhancing online web capabilities (Jarvenpaa et al., 1999; Singh and Pereira, 2005). Existing research shows that the use of language, signs and symbols, and web content that is culturally different from the host country creates confusion, frustration, offensiveness and in the long run a loss of business (Luna, Peracchio, and Juan, 2002).

To overcome these obstacles, companies have started to localize their international web sites to their customer expectations. Web site localization is the process of customizing the visible content of the web site for a specific cultural group so that it may seem natural or "local" to members of that particular culture (Singh, Toy, and Wright, 2009). Past studies have shown that web site localization can have a significant impact on consumer acceptance of the web sites (Cyr and Lew, 2003; Singh and Pereira, 2005). Effective localization can produce a $200 \%$ increase in the e-sales of a company outside its language borders (Tixier, 2005). Previous research has shown that culturally sensitive web content enhances the site's usability (Luna, Peracchio, and de Juan, 2002; Singh and Pereira, 2005). So, in order to effectively communicate with international online consumers, it is paramount for firms to adapt their web sites to the target market. Furthermore, research has shown that not only does web site localization enhance usability but also attitude towards the web site, perception of the ease of site navigation, and ultimately purchase intention (Singh et al., 2006). Despite this emerging research supporting the need for web localization, there are not many studies in academic or business press that provides $\mathrm{B} 2 \mathrm{~B}$ marketers with guidance to localize their web sites for international markets. Review of past research found only a few studies that have attempted to study web site localization efforts (Cyr and Lew, 2003; Singh and Boughton, 2005; Singh and Pereira, 2005; Singh et al. 2009; Cyr and Trevor-Smith, 2004; Tixier, 2005) and these studies primarily focused on business to consumer (B2C) context or general ecommerce. Some B2B studies have examined B2B web design characteristics and the role of culture in B2B web design, but have not proposed a comprehensive framework for localizing B2B web sites (Chakraborty, Lala and Warren, 2003; Lord and Collins, 2002; Usunier, Roulin and Ivens, 2009; Usunier and Roulin, 2010). In fact, Lichtenthal and Shay (2003) note that to build a general theory of B2B Internet integration, we should build knowledge of emerging patterns in B2B web activity. Thus this study aims to specifically address the issue of (B2B) web site localization for international markets. A three tier B2B web localization assessment framework is proposed that can help B2B companies adapt their site to both industry and international customer expectations. The three tiers or the three C's of B2B localization proposed include:

- Context Localization: at this tier the framework proposes how to localize B2B web sites to meet specific B2B industry/client expectations.

- Content Localization: at this tier the framework proposes how to localize B2B web sites to specific country/market locale by adapting elements like language translation, navigation structure, support and global gateways.

- Cultural Localization: at this tier the framework proposes how to culturally localize the content of the web site to specific country/market locale.

To develop and apply this assessment framework, we tested it on U.S. B2B web sites developed specifically for South Korea. South Korea was deemed appropriate for this study for several reasons. First, the United States and South Korea use totally different languages, 
allowing us to test level of adaptation and localization related to language. Second, the U.S. culture is significantly different from that of South Korea in many respects. Third, since South Korea is one of the wellto-do economies, there is a significant business activity at the B2B level.

\section{Standardization versus Localization}

The international business literature has explained the internationalization of firms via the stage-model proposed by Johnson and Vahlne (1999)—also called the Uppsala School internationalization model. This model suggests that firms expand in stages, where once multinational corporations gain enough experience to reduce liability of newness, they further explore growth and investment opportunities in other locations. However, in the new networked economy, the interconnectedness and reach of the Internet is now enabling firms to make internationalization decisions based on much better information than before. The Internet allows them to have web presence with minimal country-specific investments. In fact, firms leveraging the internet for internationalization closely resemble the "born global firms" proposed by Knight and Cavusgil (1996); these are defined as companies that from inception are involved in exporting and reaching out to global markets.

However, for most born global firms, leveraging the global reach of the web through standardized web sites may not be the most effective way to attract international visitors. The web is no longer dominated by English speaking online users (B2C and B2B users), but also Chinese (509.9 million), Spanish (164.9 million), Japanese (99.1 million), Portuguese (82.5 million), and German (75.4 million) speaking online users respectively (Internetworldstats.com, 2011). Thus, companies have to decide whether to create localized web content, to cater to a large multilingual worldwide market, or to create standardized content that may or may not cater to online multilingual diversity.

Standardization is generally defined as a strategy wherein marketers assume global homogeneous markets and in response offer standardized products and services using a standardized marketing mix (Jain, 1989; Levitt, 1983). Proponents of the standardization approach argue that as technology advances and spreads globally, cultural distance becomes less relevant, leading to convergence of national cultures into a homogenous global culture (Levitt, 1983). Thus, there is little need to adopt a localized marketing mix (Levitt, 1983). One of the main benefits of using a standardized strategy is that standardization seems to be an economical strategy for marketers as it leads to leveraging the same template/product or service marketing mix configuration globally. This allows companies to take advantage of economies of scale. For example, if companies could leverage their home country web site for all countries, this would significantly reduce localization expenses. In addition, using a standardized strategy can aid in the development of single and unified brand and corporate identity across markets and even worldwide. This could lead to better allocation of resources, higher efficiencies, homogenized marketing and higher profits.

Despite the above attractive benefits of standardization, there are also several concerns regarding the use of this strategy. First, several studies show that standardization as a strategy does not impact financial performance of firms (e.g. Samiee and Roth, 1992). Second, the international marketing environment is fairly complex, promoting diversity in several areas such as physical environment, political and legal systems, cultures, product usage conditions and economic development. Most importantly, in both B2C and B2B context, globally competitive companies may find it hard to standardize customer service, distribution, pricing, and communications when global variations in institutions, cultures, and other peculiarities are considered. Thus, researchers (Hill and Still, 1984; Wind, 1986) argue that it is neither desirable, nor feasible, for firms in several industries to achieve standardization of their marketing activities because of differences across markets. Finally, from an e-commerce perspective, there is large body of evidence suggesting that local users tend to favor localized web content over standardized web sites (e.g. Singh and Pereira, 2005). In fact, several B2B oriented companies are following an e-commerce strategy which emphasizes localization of their web site content. For example, a study by Boudreau and Watson (2006) of global and country-specific web sites of $3 \mathrm{M}$ found that $3 \mathrm{M}$ is following a transnational Internet advertising strategy. The signs of this transnational strategy were apparent in the large degree of global integration and local responsiveness practiced on the 3M web sites (Singh, 2012).

\section{Localizing B2B Web Sites}

The growth of global B2B e-commerce can be attributed to factors such as globalization of supply chains, growth in outsourcing activities, emergence of e-marketplaces, the global reach, access, and low entry barriers that web provides to small and medium size enterprises (Berthon, et al., 2008; Lawson-Body and Keefe, 2006; Samiee, 2008). B2B e-commerce relates to various forms of electronic platforms, including company web sites and emarketplaces, that facilitate transactions, 
interactions, and collaborations among multiple firms (Lawson-Body and Keefe, 2006; Wang and Archer, 2004). B2C e-commerce, on the other hand, is more geared towards selling and communicating with masses of consumers rather than a select group of business clientele. Some differences in B2B and B2C e-commerce are captured in Table 1.

Several studies (e.g. Chakraborty et al., 2003; Dou et al., 2002; Lord and Collins, 2002) have identified important $\mathrm{B} 2 \mathrm{~B}$ web design characteristics related to personalization, transactional ease, product information presentation, product quality and certification information, technical support, corporate citizenship, pricing information etc. These studies show that B2B web sites design characteristics tend to be different from B2C web design, due to the unique B2B context. Studies have also shown that, even in the B2B context, culturally localizing web sites is important to effectively communicate with customers worldwide (Dou et al., 2002; Usunier et al., 2009; Usunier and Roulin, 2010). For example, studies by Usunier et al., (2009) and Usunier and Roulin (2010) have specifically explored the role of communication styles (high context and low context cultural communication) and cultural values in design of B2B web sites and provided recommendations for cultural adaptation of international B2B web sites.

Furthermore, the literature also identifies several broad challenges to the growth of global ecommerce in general and B2B e-commerce in specific. Such challenges include cultural diversity of the global online marketplace and the cultural distance; the information asymmetry; differences in the institutional, managerial and infrastructural environment among countries; differences in evolution of e-readiness among countries; and differences in levels of corruption (Berthon et al., 2008; Samiee and Walters, 2006). More specific challenges pertaining to global growth of B2B ecommerce include online risks associated with security of transactions process; online payment issues; online order fulfillment; online information disclosure; collection, usage and storage of personal information online (privacy risk); unauthorized access to internal systems; password sniffing; data modification; spoofing; repudiation and potential opportunism among parties (Angeles and Nath, 2007; Dou et al., 2002; Ratnasingam, 2007).There are also significant costs associated with global B2B e-commerce and web site development. These costs range from more general transaction costs related to doing arm's length transactions (Williamson, 1975), to costs related to international negotiations, administrative-legal costs, costs associated with development of e-procurement systems and scalable online applications, global-real-time integration of business process in supply chain, ERP application implementation, and interoperability costs to efficiently connect with heterogeneous trading partner applications (Angles and Nath, 2007; Ratnasingam, 2007). These risks and costs associated with the conduct of global B2B ecommerce generate a high degree of uncertainty related to the e-business environment and, most

Table 1. Differences between B2B and B2C e-commerce

\begin{tabular}{|c|c|c|}
\hline & B2B E-Commerce & B2C E-Commerce \\
\hline 1 & $\begin{array}{l}\text { As the name suggests that } \\
\text { B2B e-commerce is geared } \\
\text { towards a group of business } \\
\text { clientele and not general } \\
\text { public }\end{array}$ & $\begin{array}{l}\text { B2C e-commerce serves } \\
\text { the mass } \\
\text { consumers/general public. }\end{array}$ \\
\hline 2 & $\begin{array}{l}\text { Sales in B2B context are } \\
\text { based on contracts, bidding } \\
\text { process, and sometimes } \\
\text { lengthy trade negotiations }\end{array}$ & $\begin{array}{l}\text { Sales in B2C arena are } \\
\text { based on individual level } \\
\text { transactions, generally on } \\
\text { real-time basis. }\end{array}$ \\
\hline 3 & $\begin{array}{l}\text { Payment systems are } \\
\text { based on negotiated terms } \\
\text { of contract and generally } \\
\text { accompany services like } \\
\text { escrow accounts \& credit } \\
\text { terms. }\end{array}$ & $\begin{array}{l}\text { Payments are normally } \\
\text { taken using popular online } \\
\text { payment systems and } \\
\text { generally happen in real- } \\
\text { time. }\end{array}$ \\
\hline 4 & $\begin{array}{l}\text { Exchange is generally } \\
\text { based on long-term } \\
\text { relationship building and } \\
\text { repeat interactions (Samiee } \\
\text { and Walters, 2006) }\end{array}$ & $\begin{array}{l}\text { Exchange is generally } \\
\text { based on one-time } \\
\text { transaction, although } \\
\text { relationship marketing is } \\
\text { becoming popular in } \mathrm{B} 2 \mathrm{C} \text { e- } \\
\text { commerce. }\end{array}$ \\
\hline 5 & $\begin{array}{l}\text { Issues of governance of } \\
\text { exchange transactions and } \\
\text { risk of opportunism is much } \\
\text { more profound in B2B e- } \\
\text { commerce context (Samiee } \\
\text { \& Walters, 2006; } \\
\text { Williamson, 1975) }\end{array}$ & $\begin{array}{l}\text { Governance and } \\
\text { opportunism in } \mathrm{B} 2 \mathrm{C} \text { are not } \\
\text { as profound as in } \mathrm{B} 2 \mathrm{~B} \text { e- } \\
\text { commerce. In } \mathrm{B} 2 \mathrm{C} \text { risk of } \\
\text { opportunism still exists but } \\
\text { is somewhat mitigated by } \\
\text { nature and type of } \\
\text { exchange transactions. }\end{array}$ \\
\hline 6 & $\begin{array}{l}\text { Applications used to } \\
\text { facilitate B2B e-commerce } \\
\text { include e-procurement } \\
\text { systems, bidding systems, } \\
\text { ERP solutions related to } \\
\text { supply chain management } \\
\text { and CRM. }\end{array}$ & $\begin{array}{l}\text { Generally application } \\
\text { integration with end-users is } \\
\text { not required. Common form } \\
\text { of applications used in B2C } \\
\text { context include, e-catalogs, } \\
\text { search function, online } \\
\text { payment systems, security } \\
\text { systems etc. }\end{array}$ \\
\hline 7. & $\begin{array}{l}\text { Interoperability is important } \\
\text { to facilitate the integration } \\
\text { and exchange of data and } \\
\text { information between the } \\
\text { systems of the trading } \\
\text { parties. (Legner and Vogel, } \\
\text { 2008) }\end{array}$ & $\begin{array}{l}\text { Interoperability is generally } \\
\text { not a major issue with B2C } \\
\text { clients except the } \\
\text { integration via web services } \\
\text { to mobile interface. }\end{array}$ \\
\hline
\end{tabular}


importantly, between trading parties (Ratnasingam and Phan, 2003). Relationship building based on high degree of trust becomes crucial to counteract the uncertainties associated with the conduct of global B2B e-business (Samiee and Walters, 2006; Ratnasingam and Phan, 2003). Thus, any framework or recommendation for B2B international web site development should take into account the importance of trust, and costs and risks related to the conduct of global B2B e-business activity. In the following sections, a framework for B2B web site localization assessment and development is proposed. This framework takes into account the specific challenges of conducting global B2B ebusiness and the diversity of standards, norms and values found in the international context.

\section{Factors Influencing the Localization Framework}

Before elaborating the framework for localizing B2B international sites, it is important to lay down the foundations which are necessary for localization efforts to be successful. Some of the important technical issues discussed in this section include the importance of a global modular web site platform which could be leveraged for creating several localized sites, and the need for using open standards for future inter-firm application integration and interoperability of data.

\section{Internationalization (i18n):}

Internationalization or $118 n$ in the context of web site development is different than how we interpret internationalization in international business vocabulary. Broadly speaking "Internationalization" in context of international web site development is a technical term used for the process of generalizing a product so that it can handle multiple languages and cultural conventions. More specifically, the process through which back end technologies are used to create a modular, culturally neutral, extendable, and accessible global web site template is called "Internationalization", or $\mathrm{i} 18 \mathrm{n}^{1}$ (Singh and Boughton, 2005, Singh, 2012). Internationalization helps companies develop a global platform or web architecture for future localization efforts (Al-Badi and Mayhew, 2010). However, many companies, in their haste localize international sites, or due to insufficient resources, ignore this important back end process and develop separate global templates for different countries, thus creating inefficiencies and

i18n" stands for Internationalization, since there are 18 letters between $\mathrm{i}$ and $\mathrm{n}$. (note: a small "i" is used to distinguish it from the letter "l" and the number "1".) expenses associated with developing a new base platform for every new language/country web site. For example, if companies develop new internationalized templates for every international site then chances of coding errors increases and so does the cost of quality control and maintenance. If companies create a well internationalized and culturally neutral base platform, then this single base platform could be leveraged for localizing web sites for every new language/country. Several big tech companies such as Sun Microsystems, Microsoft, IBM, Google, etc. take the Internationalization-Step seriously, but Internationalization is still not well implemented by several non-tech large companies and many SMEs. For example, according to Singh (2012), most companies do not have the expertise to implement the Internationalization-Step properly and, thus, outsource such work to localization vendors. The Internationalization-Step ensures that a modular approach to design is taken, wherein the software/web site supports international characters, date and time formats, number formats, address fields, text expansion and contraction, and other locale specific elements (Esselink, 2000). Thus, in a nutshell, Internationalization (i18n) processes provide the essential foundation upon which to build future localization efforts. An extended discussion on all the Internationalization steps and processes is beyond the scope of this paper. It is recommended that companies use the expertise of software engineers or outsource the work to localization vendors who specialize in internationalizing web sites and applications. Companies must also realize that Internationalization-Step should be completed before localization step is undertaken to develop multilingual web sites. The Internationalizion-Step should generally be done at home office or at the main technology department wherein software engineers can create a culturally neutral and modular platform for future localization efforts to be depicted seamlessly. On the other hand, the localization step could be carried out at local offices, or the head office should ensure that local subsidiaries or local/country level offices have a say in how the web site should be localized to specific culture/country.

\section{Interoperability:}

In the B2B e-business environment, it is important to be able to integrate and communicate with applications and systems of the trading parties for the exchange of information. A new movement toward dynamic e-business is now geared toward simplifying and standardizing business interactions over the web through Internet based open standards and common infrastructure (Chen et al., 2003). 
Interoperability is now seen as the key to facilitating dynamic e-business. Interoperability is the ability to integrate two or more systems or components in business processes for exchange and use of information (Kajan and Stoimenov, 2005; Legner and Vogel, 2008). XML (Extensible Markup Language) is one of the open standards that facilitates interoperability and is used to store and transport data over the web, intranets, extranets, etc. Kajan and Stoimenov (2005, p. 62) identify three levels of interoperability which, include:

- Communication Interoperability: depends on standards and infrastructure where all necessary data is well defined. "There is no machine knowledge required, but it may be deployed; for instance, using intelligent agents for network maintenance (p. 62)".

- Syntactic Interoperability: is seen when two or more systems/software components can communicate and exchange data independent of their implementation language, run time environment and technological differences.

- Semantic Interoperability: is a much advanced form of interoperability, wherein the systems can communicate without understanding the terminology of their systems. It overcomes semantic differences across heterogeneous data sources.

In recent years "Web Services" have emerged as a vehicle for enhancing interoperability between heterogeneous systems. Web services are based on open standards facilitating direct interaction among systems using XML-based messages conveyed by the Internet protocols (Chen et al., 2003).Web services use other open standards, like SOAP to transfer data and WSDL for service interface descriptions (Chen et al., 2003; Legner and Vogel, 2008). In essence, web services allow dynamically connecting systems, business partners and customers in a cost effective way using the open and free medium of the web (Chen et al., 2003). In summary, it is important for companies to create B2B e-business environments based on open standards that enhance interoperability between systems and clients. Both Internationalization (i18n) and interoperability are important technical requirements needed to prime the web sites for future localization efforts. These technical requirements ensure that the web site is neutralized and flexible enough to incorporate future variations in standards, conventions, languages, etc.

\section{The B2B Web site Localization Framework Assessment}

Once the company has prepped and internationalized its web site and used open standards for application development, the next step is to localize the web site to meet specific client and locale needs. The remainder of the study will discuss how to implement certain web site features that can help localize the B2B web site to international audiences.

B2B costs and risks could be mitigated by reducing the risk of opportunism and developing mechanisms, applications, and platforms that engender trust. One of the main objectives of localizing web sites is to develop and display trust through web site content and application. Customers are more likely to trust the "familiar" than the "stranger", so localizing a web site puts it in the realm of the familiar for the consumers, thus enhancing consumer trust.

The broad literature in web and user interface localization has been in general e-business and Business to Consumer context (Cyr and Lew, 2003; Singh and Boughton, 2005; Singh and Pereira, 2005; Singh et al. 2009; Cyr and Trevor-Smith, 2004; Tixier, 2005). In B2B literature most studies have looked into specific B2B web design characteristics or addressed localization issues from cultural adaptation perspective (Chakraborty, Lala and Warren, 2003; Lord and Collins, 2002; Usunier, Roulin and Ivens, 2009; Usunier and Roulin, 2010). More specifically, past studies in the field of web localization can be divided into four broad categories: studies providing general usability guidelines for international user interface design (Becker, 2002; Esselink, 2000; Nielsen and Del Galdo, 1996; Cyr and Trevor-Smith, 2004), studies proposing general frameworks for developing international web sites (Al-Bade and Mayhew, 2010; Al-Badi and Naqvi, 2010; Becker, 2002; Becker and Crespo, 2001; Dou et al., 2002; Singh, 2012; Singh et al., 2009), surveys and studies pertaining user perception of international web sites and international online user profiles (Baack and Singh, 2007; Nantel and Glaser, 2008; Wallace and Yu, 2009; Singh et al., 2006; Singh, 2012), and studies that have specifically explored how to culturally localize web sites (Barber and Badre, 1998;Baack and Singh, 2007; Cyr and Lew, 2003; Cyr and Trevor-Smith, 2004; Singh and Pereira, 2005; Singh, et al., 2009; Usunier, et al., 2009; Usunier and Roulin, 2010). Most of the past research has specifically looked into usability, cultural, and functional level factors to localize international web sites. For example, study by Singh et al. (2009) primarily measured web localization in B2C context on dimensions of content localization 
and cultural customization. Studies by Al-Badi and Mayhew (2010), Al-Badi and Naqvi (2010), and Becker (2002) provided usability considerations related to localizing web sites in terms of navigation, page design, cultural issues, information content and other functional features.

Thus, past web localization frameworks have provided various web usability and design elements that need to be considered when localizing any ecommerce web site. The goal of this study is to extrapolate from the past work and enrich the literature by specifically proposing a framework to localize B2B web sites. As elaborated in the past sections, trust-generating elements are much more crucial in B2B context than B2C context. None of the past frameworks we studied have included specific trust generating features as a part of a framework to localize B2B web sites. Thus, the framework proposed in this study for B2B international web site localization not only takes into account the cultural and linguistic issues, but also considers the importance of trust development in the B2B ecommerce environment. Therefore, the B2B web localization framework is divided into three localization dimensions namely: context localization for emphasizing elements to generate trust and enhance communication, content localization dealing with elements that need to be adapted depending on locale-specific/national requirements, and cultural localization for adapting the site content to cultural expectations of the society.

\section{Context Localization}

B2B international e-business context is unique and quite different from that of $\mathrm{B} 2 \mathrm{C}$ e-business, as elaborated in previous sections of the paper and Table 1. In international B2B e-business context, relational exchanges are crucial for reducing information asymmetry, enhancing coordination, reducing the risk of opportunism and transaction risk, and enhancing long term cooperation and value of partnerships (Lancaster and Lages, 2006; Samiee and Walters, 2006). Consumer trust has frequently been studied in relationship marketing as an important determinant of relationship development (e.g. Bart, Shankar, Sultan and Urban, 2005; Dwyer, Schurr and Oh, 1987; Garbarino and Johnson, 1999; Moorman, Deshpandé and Zaltman, 1993; Morgan and Hunt, 1994; Palmatier, Dant, Grewal and Evans, 2006). In the global context, engendering online trust is even more important, as commonly associated sources of trust like prior knowledge of the merchant, familiarity with the business, and social and legal structures are missing (Jarvenpaa et al, 1999). According to Lancaster and Lages (2006), when customers have trusting relationships with other online suppliers, they are more willing to share information and cooperate. Thus, cooperative relationships are based on a high degree of trust and facilitated by communication leading to longterm relationship-specific investments (Dwyer, et al., 1987; Morgan and Hunt, 1994; Lancaster and Lages, 2006; Samiee and Walters, 2006). Samiee and Walters (2006) identify trust, relationshipspecific investments and effective communication as some of the important determinants of B2B relational exchange in a global context. The proposed framework adopts determinants of international relational exchange proposed by Samiee and Walters (2006) (trust, relationship-specific investments and communication) to localize web sites to international B2B online context.

\section{Trust}

To depict trust on international B2B web sites, we propose two sets of trust-based web features, which highlight institution-based trust and process-based trust. According to Zucker (1986), institution-based trust can be engendered via incorporating societal or professional norms and structural assurances like legal terms, guarantees, dispute resolution and other procedures to generate trust. Table 2.1 outlines three institution-based web features based on past studies by Lawson-body and Keefe (2006), Lord and Collins (2002), Pavlou (2002), Pavlou and Gefen (2004), Son, Tu and Benbasat (2006), Usunier and Roulin (2010) and Zucker (1986) namely; structural safeguards, cooperative norms, and trust generating third-party assurance seals.

Process-based trust has been shown to be produced when parties have direct interactions or have indirect knowledge about the other party's reputation (Son et al., 2006; Zucker, 1986). Therefore, web features that highlight a company's social capital and reputation can help generate process-based trust (Son et al., 2006). Table 2.1 outlines four process-based web features based on past studies by Anderson and Weitz (1989), Ganesan (1994), Samiee and Walters (2006), Son et al., (2006) and Zucker (1986) namely; partnerships/affiliations with respected organizations, company standing and performance, company management, and company recognition.

\section{Relationship-specific Investments}

Relationship-specific investments deal with developing assets that support specific transactions between the firm and its customers (Williamson, 1975). This entails investing time, resources and efforts to build long-term relationships with specific customers (Samiee and Walters, 2006). 
Relationship-specific investments show firms commitment to long-term relationship orientation and reduces the risk of opportunism (Anderson and Weitz, 1992). Relationship-specific investments create higher online switching costs, leading to greater interdependence between parties (Lancaster and Lages, 2006). Furthermore, such investments entail that the parties feel a sense of credibility and reliability when conducting online transactions (Pavlou, 2002).

Table 2.1. Context Localization Trust features

\begin{tabular}{|l|l|}
\hline $\begin{array}{l}\text { 1. Institution } \\
\text { Based Trust } \\
\text { features }\end{array}$ & Items \\
\hline $\begin{array}{l}\text { 1. Structural } \\
\text { Safeguards }\end{array}$ & $\begin{array}{l}\text { Information about any escrow service } \\
\text { being used by the company, a return policy } \\
\text { providing insurance for faulty } \\
\text { products/unexpected return, product } \\
\text { quality, cancellation policy, repair or } \\
\text { replacement guarantees or warranties for } \\
\text { product/service/credit cards. }\end{array}$ \\
\hline $\begin{array}{l}\text { 2. Cooperative } \\
\text { Norms }\end{array}$ & $\begin{array}{l}\text { Information on dispute resolution, } \\
\text { arbitration, ethical code of conduct, terms } \\
\text { and conditions of use-perhaps a web } \\
\text { page or a section on codes of conduct or } \\
\text { terms and conditions of use. }\end{array}$ \\
\hline $\begin{array}{l}\text { 3. Trust } \\
\text { Generating } \\
\text { Third-Party } \\
\text { Assurance Seals }\end{array}$ & $\begin{array}{l}\text { Privacy seals, security seals, reliability } \\
\text { seals, Quality seals like ISO standards } \\
\text { organization }\end{array}$ \\
\hline $\begin{array}{l}\text { 2. Process } \\
\text { Based Trust } \\
\text { features }\end{array}$ & Items \\
\hline $\begin{array}{l}\text { 1.Partnerships/af } \\
\text { filiations with } \\
\text { Respected } \\
\text { organizations } \\
\text { (industrial } \\
\text { associations) }\end{array}$ & $\begin{array}{l}\text { Links to partner sites; partner logos; co- } \\
\text { brand name citations; co-brand and partner } \\
\text { reputation; partner network affiliations; } \\
\text { security partner reputation, affiliation to } \\
\text { industry associations. }\end{array}$ \\
\hline $\begin{array}{l}\text { 2.Company } \\
\text { standing and } \\
\text { performance }\end{array}$ & $\begin{array}{l}\text { Information on company profile related to } \\
\text { volume of transactions, number of clients, } \\
\text { business size, company history/longevity }\end{array}$ \\
$\begin{array}{l}\text { 3.Company } \\
\text { Management } \\
\text { Vision statement, mission statement, } \\
\text { management team profile } \\
\text { recognition }\end{array}$ & Customer testimonials, awards, good PR. \\
\hline
\end{tabular}

Thus, to create a sense of relationship companies not only need online mechanisms to enhance personalization, but also need to reduce perceived risk of opportunism. Thus, based on the review of the literature the following items were identified for building online relationship-specific investments: availability of dedicated web services using extranets, intranets, ERP software, web site personalization, and transactional security for reducing perceived risk (Bart, et al., 2005; Chakraborty et al., 2003; Chen et al., 2003; Pavolu, 2002; Usunier and Roulin, 2010; Wilson and Abel, 2002) (Table 2.2).

Table 2.2. Context Localization: Relationship Specific Investments

\begin{tabular}{|l|l|}
\hline $\begin{array}{l}\text { 1. Web site } \\
\text { personalization }\end{array}$ & $\begin{array}{l}\text { Site registration, ability to customize the site } \\
\text { for a user, virtual simulations based on } \\
\text { customer needs, configuration of } \\
\text { product/service/price to individual customer } \\
\text { requirements }\end{array}$ \\
\hline $\begin{array}{l}\text { 2. Availability of } \\
\text { Dedicated Web } \\
\text { services }\end{array}$ & $\begin{array}{l}\text { Use of extranet for dedicated customer } \\
\text { pages, SFA-ERP applications, order } \\
\text { tracking, customer recommendation system, } \\
\text { product/price comparison features. }\end{array}$ \\
\hline $\begin{array}{l}\text { 3. Transactional } \\
\text { Security }\end{array}$ & $\begin{array}{l}\text { Security policy, Security-statements to } \\
\text { engender trust/ - payment security } \\
\text { procedures and options; transactions } \\
\text { security; transparency; ".https-address"; } \\
\text { download security; latest security standards; } \\
\text { SSL-Standard (Secure Socket Layer); CVV } \\
\text { code for credit card payment; data } \\
\text { encryption }\end{array}$ \\
\hline
\end{tabular}

Table 2.3:. Context Localization: Communication

\begin{tabular}{|l|l|}
\hline $\begin{array}{l}\text { 1. Contact } \\
\text { Information }\end{array}$ & $\begin{array}{l}\text { Basic contact methods like e-mail, phone, } \\
\text { dealer locator, fax, local map }\end{array}$ \\
\hline 2. Online Help & $\begin{array}{l}\text { Virtual vendor advice-real-time chat; hot line } \\
\text { number; online/ offline help; frequently } \\
\text { asked questions; brick-and-mortar } \\
\text { references for further advice and product } \\
\text { demonstrations; call-back option, PDF or } \\
\text { FTP download available }\end{array}$ \\
\hline $\begin{array}{l}\text { 3. Community } \\
\text { features }\end{array}$ & $\begin{array}{l}\text { Quality and meaningfulness of membership } \\
\text { features (e.g. blogs, wikis, forums); other } \\
\text { users' comments and reports }\end{array}$ \\
\hline
\end{tabular}

\section{Communication}

Several studies have shown that communication styles matter on the Web (e.g., Baack and Singh, 2007). Communication has been shown to be critical to all aspects of relational exchanges, including development and maintenance of long term relational exchange (Cunningham and Homse, 1986; Mohr and Nevin, 1990; Tyler, Stanley and Brady, 2006). The role of communication and feedback in trust development and relationship efficiency is well documented in the literature (Anderson and Narus, 1990; Morgan and Hunt, 1994; Pavlou, 2002; Samiee and Walters, 2006). Online feedback mechanisms, such as communities or other web features that enhance buyer-seller dialogue, are shown to enhance trust-building intentionality (Doney and Cannon, 1997; Pavlou, 2002). Thus, based on a review of the 
literature the following elements of communication were identified to enhance context localization: presence of contact information, online mechanisms to provide online help and advice, and online community features (Bart et al., 2005; Doney and Cannon, 1997; Dou et al., 2002; Pavlou, 2002; Pavlou and Gefen, 2004). The items to measure communication are listed in Table 2.3.

\section{Content Localization}

Several studies have shown that international online users prefer web sites that are specifically configured functionally and linguistically to their locale (Cyr and Trevor-Smith, 2004; Singh and Pereira, 2005). To successfully localize web site content, factors such as language, cultural preferences, content currency, and navigation, should be considered in the web site design (Singh and Boughton, 2005; Singh, et al., 2009; Cyr and Trevor-Smith, 2004; Usunier et al, 2009; Usunier and Roulin, 2010). Singh and Boughton (2005) measured web localization in terms of content adaptation to a locale to accommodate elements like language translation, navigation structure, use of appropriate colors and graphics, global gateway for different language sites, and culturally relevant web content. The variables that measure content localization provide a general understanding of how the company has localized the basic web content to a specific locale (Singh et al., 2009). In this study we adapt the elements of content localization proposed by Cyr and Lew (2003), Cyr and Trevor-Smith (2004), Singh and Boughton (2005) and Singh et al. (2009). Content localization in this study is measured on the equivalency and relevancy of localized content and navigational quality. In the following sections we describe the web features that can be used to enhance content localization. Table 3 also provides a list of these items and how they are measured.

Translation Depth: The study measures the depth of translation available on international web sites by reviewing whether all primary links ${ }^{2}$ from the home country web site are translated in the local language (Table 3).

Currency, Navigation, and Web Support: This construct addresses the relevancy, navigation, and localized online support quality of the international web site's content compared to the home country web site. It measures the extent to which the localized site is updated compared to the home country site, and also how well the navigation on the localized site compares with the home country site. In addition, the

\footnotetext{
2 Primary links are the links seen on the main menu
} featured on the home page of a web site. construct also takes into account the extent to which the online support services on the international site are equivalent to the home country site and localized. These variables provide a general understanding of how the company has localized the basic web content to the local audience (Table 3). The variables are derived from previous studies by Al-Badi and Mayhew (2010), Beck (2002), Cyr and Lew (2003) and Singh and Boughton (2005), and Singh et al., (2009).

Table 3. Content Localization

\begin{tabular}{|c|c|}
\hline & Items \\
\hline \multicolumn{2}{|l|}{ Linguistic Variables } \\
\hline \multicolumn{2}{|l|}{ Language Pages } \\
\hline $\begin{array}{l}\text { 1. Number of English } \\
\text { Pages }\end{array}$ & $\begin{array}{l}\text { Number of English-language web pages } \\
\text { on each web site }\end{array}$ \\
\hline $\begin{array}{l}\text { 2. Number of Korean } \\
\text { Pages }\end{array}$ & $\begin{array}{l}\text { Number of Korean-language web pages } \\
\text { on each web site }\end{array}$ \\
\hline \multicolumn{2}{|l|}{ 1. Language Usage } \\
\hline $\begin{array}{l}\text { 1. Percent of Korean } \\
\text { Translated Web } \\
\text { Pages }\end{array}$ & $\begin{array}{l}\text { Ratio of Korean web pages divided by } \\
\text { English web pages }\end{array}$ \\
\hline 2. $\quad$ Content Depth & $\begin{array}{l}\text { Extent of the content made available } \\
\text { to Korean online users in terms of } \\
\text { contact information, product } \\
\text { information, services, company } \\
\text { information, shipping, and handling ( } 1 \\
\text { = basic store and contact information; } \\
5 \text { = all sections from English pages } \\
\text { are translated and have all } \\
\text { information needed for Korean } \\
\text { customers) }\end{array}$ \\
\hline \multicolumn{2}{|c|}{ 2. Currency, Navigation and Support } \\
\hline $\begin{array}{ll}\text { 1. } & \text { Content } \\
& \text { Synchronization }\end{array}$ & $\begin{array}{l}\text { Currency of the Korean site content } \\
\text { relative to the source - English site } \\
\text { content }(1=\text { content is out of synch } \\
\text { with English content; } 5=\text { most Korean } \\
\text { content is in synch with the English } \\
\text { content) }\end{array}$ \\
\hline 2. Navigation & $\begin{array}{l}\text { Extent to which the web site has an } \\
\text { adequate site map, hyperlinks, } \\
\text { forward and backward buttons, } \\
\text { directories, FAQs, and on-line search } \\
\text { help on the Korean portion of the web } \\
\text { site ( } 1 \text { = very poor navigation } \\
\text { attributes; } 5=\text { very good navigation } \\
\text { attributes) }\end{array}$ \\
\hline $\begin{array}{l}\text { 3. Web Site Service } \\
\text { and Support }\end{array}$ & $\begin{array}{l}\text { Extent to which the Korean online } \\
\text { customer support is equivalent to that } \\
\text { offered on the English web pages ( } 1= \\
\text { no online support for Korean web } \\
\text { pages; } 5=\text { web site support that is } \\
\text { better than what is provided on the } \\
\text { English web pages). }\end{array}$ \\
\hline
\end{tabular}


Table 4: Cultural Customization

\begin{tabular}{|ll|l|}
\hline \multicolumn{2}{|c|}{ Cultural Customization } \\
\hline 1. & $\begin{array}{l}\text { Web Page } \\
\text { Structure }\end{array}$ & $\begin{array}{l}\text { Overall design and feel of web site (1 = } \\
\text { standardized based on the English portion } \\
\text { of the web site; 5 = unique based on Korean } \\
\text { cultural foundations) }\end{array}$ \\
\hline 2. & Graphics & $\begin{array}{l}\text { Presence of pictures related to Korean } \\
\text { culture and the use of cultural symbols (1 = } \\
\text { standardized features based on the English } \\
\text { portion of the web site; 5 = unique } \\
\text { characteristics that reflect Korean cultural } \\
\text { norms) }\end{array}$ \\
\hline 3. Colors & $\begin{array}{l}\text { 1. no sensitivity to Korean national colors--- } \\
5 . \text { Korean national colors represented well }\end{array}$ \\
\hline 4. & Translation & $\begin{array}{l}\text { Quality of translation into Korean in terms of } \\
\text { appropriate word use, conceptual } \\
\text { equivalence, idiomatic equivalence, and } \\
\text { vocabulary equivalence (1 = very poor } \\
\text { quality; 5 = very good quality) }\end{array}$ \\
\hline
\end{tabular}

\section{Cultural Localization}

Studies have shown that cultural customization of web sites can lead to better navigation, usage, attitude toward the site and even higher purchase intentions on the site (Singh and Pereira, 2005). According to Luna, Peracchio, and de Juan (2002), culturally congruent web content decreases cognitive effort to process information on the site, and represents an environment where demands are clearer, leading to easier navigation and a more favorable attitude toward the web site. In fact, recent research shows growing empirical evidence to suggest that the web is not a culturally neutral medium, and web sites of different countries are impregnated with cultural values unique to them (Cyr and Trevor-Smith, 2004; Hermeking, 2005; Singh and Matsuo, 2004; Singh, Zhao, and Hu, 2003; 2005). Mayer-Guell (2001) argues that for B2B ecommerce to be successful, it must emphasize in its communications an organizational and cultural it.

The study by Berthon et al., (2008) found that e-B2B marketers must understand country cultural values in order to successfully develop transnational B2B relationships. Thus, it is important to address the global audience on the Internet in their own language and in a style that is culturally congruent to their local conventions (Singh and Boughton, 2005; Usunier and Roulin, 2010). Past studies in B2C context have provided frameworks for extensive cultural customization (e.g. Singh and Pereira, 2005), but since in B2B context extensive cultural customization may not be needed, we propose to measure cultural localization by analyzing whether the international B2B web site has been specifically designed for a particular country, considering colors, symbols, spatial orientation and translation quality (Singh and Boughton, 2005; Singh and Pereira, 2005; Singh et al., 2009) (Table 4).

\section{Methodology}

\section{Face Validity Test}

A face validity test was conducted to ensure reliability and mutual exclusivity of our categories. We invited five PhD students at a mid-western U.S. university and asked each of them to read the definition of each item and dimension and classify it under one of the three categories (Context, Content, and Cultural localization). We began by giving a brief definition in plain English describing each dimension and item (Table 2, 3, and 4). The respondents were then given 22 items and were asked to decide in which category each item would be classified into. We received 91 out of 110 $(82.7 \%)$ correct responses identifying the 22 variables under the three categories given in the framework. The variables where most disagreement occurred included variables such as, "Cooperative Norms" and "Web site Service and Support".

\section{Content Analysis}

To assess our framework and provide examples of how it could be applied to existing companies, we conducted a content analysis. Content analysis is a widely used tool for conducting objective, systematic and quantitative analysis of communication content (Kassarjian, 1977). Several previous studies have used content analysis for analyzing web communications and web site design elements (e.g. Singh et al., 2005). Content analysis was deemed most appropriate for this study for its ability to identify web design elements and web site structure. The unit of analysis was U.S. companies' entire web sites designed for Korean users. Two bilingual raters (fluent in both English and Korean) did a content analysis of thousands of web pages. Coders were provided with a definition of each of the variables to be tested and an explanation of these variables was provided by the researchers. Coders were trained prior to the coding process to make sure they understood what needed to be done and what was required to complete the study correctly. When an item of disagreement occurred, the coders met and reviewed the web site together to determine the final coding after discussion. To ensure that the results were reliable, an inter-rater reliability test was then calculated to check the percentage of agreement among raters coding the same web page (Kassarjian, 1977). Inter-rater reliability came to an acceptable level of $84 \%$. 


\section{Sample}

The sample for this study was generated from Fortune's list of the top 1,000 global companies. In total, 50 Korean B2B web sites by U.S. multinationals were selected for analysis. The unit of analysis was all main web pages in the web site. Each web site on average had 50 web pages. Thus, a total of 2500 web pages were analyzed for this study.

\section{Measuring B2BWeb Site Localization}

Each web site was analyzed on 24 variables (see Table 2, 3, 4). Two of the variables (Number of Korean Pages on Korean site of the US Company and Number of English Pages on American web site of the US Company) were used to test for the number and percentage of Korean Translated Web Pages variable. The 22 variables were divided into three broad categories based on the constructs discussed in the previous section of the paper: Context Localization, Content Localization and Cultural Customization.

Firstly, the Context Localization construct is composed of three broad features: Trust, Relationship-Specific Investments, and Communication. Trust features in the Context Localization construct were measured using two broad items: Institution Based Trust and Process Based Trust. Institution Based Trust was measured using three variables: Structural Safeguards, Cooperative Norms, and Trust Generating Third-Party Assurance Seals. Process Based Trust was measured using four variables: Partnerships/Affiliations with Respected Organizations, Company Standing and Performance, Company Management, and Company Recognition. Relationship-Specific Investments features in Context Localization construct were measured using three variables: Web Site Personalization, Availability of Dedicated Web Services and Transactional Security. Communication features in Context Localization construct was measured using three variables: Contact Information, Advice, and Community Features.

Secondly, the Content Localization construct is composed of three broad features: Language Usage, Currency, Navigation and Support. Language Usage features in Content Localization construct were measured using two variables: the Percentage of Korean Translated Web Pages, and Content Depth. Currency, Navigation and Support features in Content Localization construct were measured using three variables: Content Synchronization, Navigation, and Web Site Service and Support.
Lastly, Cultural Customization construct was measured using three variables: Web Page Structure, Graphics, Colors and Translation Quality.

\section{Factor Analysis}

To further analyze the data, and assess the unidimensionality of the items proposed for this framework, an exploratory factor analysis (EFA) was conducted using SPSS 18.0. EFA has been proposed as an effective technique at early stages of theory and scale development and to assist with discovery of factor structure (Hurley et al., 1997). EFA revealed that the items loaded on seven factors with loadings all higher than .3 as suggested by Hair et al. (1998). The factors obtained are included in Table 5. Factor one included four cultural items, including Cultural web page structure, Cultural graphics, Cultural colors and Content translation quality. We call factor one the cultural factor. Factor two included four items, including Contact information, Community features, Web site support and advice. All of the items except web site support belong to the context factor. Factor three had five items, including Cooperative norms, Translated web sites, Content depth, Content synchronization and Navigation.

It seems that on factor three cooperative norms is the only item not part of the content localization that loaded high on it. Factor four had three items, including Company standing and performance, Company recognition and Company management, which are all specific to process based trust construct. Factor five had three items, including Web site personalization, Availability of dedicated web services and Security, which are all relationship specific items. Factor six only had 'Partnership/Affiliation' under it. Finally, only two institution based trust items, namely, Structural Safeguards and Trust Generating Third Party Seals showed high loadings as part of factor seven.

Furthermore, we tested the internal consistency of the factors using Cronbach's alpha and checked the inter-item correlations. The results showed high reliability with alphas ranging: factor- $1(\alpha=.91)$, factor $-2(\alpha=.85)$, factor-3 ( $\alpha=.77)$, factor $4(\alpha=.90)$, factor 5 $(\alpha=.85)$. Only factor seven with items Structural Safeguards and Third Party Seals did not show acceptable reliability and since factor 6 only has one item, we could not test its reliability.

Based on the factor analysis solution it is clear that most of the items loaded on distinct dimensions as identified in the literature review. Only three items 'Partnerships/Affiliation with respected organiza- 
tions', Cooperative Norms and 'web Site support' did not load as predicted by theory.

It could be argued that in this study 'Web site Support' a Content Localization variable, which measured the extent of localization practiced in terms of providing online support, also reflects the company's ability to provide online help and advice, which is a Context Localization variable. Thus, we saw the 'web site support' variable load along with 'Online Help and Advice' variable on the Communication dimension of Context localization. Thus, researchers should take this conceptual overlap into account in future studies. The factor analysis helped us to empirically test the reliability of the proposed framework for B2B web site localization, and also helped us establish a list of mutually exclusive variables to facilitate localization of web sites in the B2B context.

The results from factor analysis also confirm the results of our face validity test, wherein items such as Cooperative Norms and Web site Services and Support did not load well on Context dimension. For example, similar to the factor analysis results, the "Web site Service and Support" was perceived to better fit the Context dimension of Communication.

Thus, results from factor analysis and face validity test lend further credence to the proposed framework. Our next step was to further test the framework using a focus group.

\section{Focus Group}

To further enhance the academic and practical relevance of the proposed framework, we conducted focus groups to uncover collective attitudes and beliefs of Internet users' expectations of B2B web localization elements. Focus groups deliver a greater breadth, depth and complexity of information, especially when the topic under consideration is relatively unexplored (Morgan, 1996). Since this is an initial study proposing a framework for B2B web localization, a qualitative research technique like a focus group was deemed appropriate. At a mid-western U.S. university, two focus groups were conducted to enhance the external validity of the focus group results. One focus group comprised of eight participants recruited from a part-time MBA program, and the other focus group included ten middle-management executives from an Executive Masters of International Business program. All participants had corporate work experience and had used the web for business dealings. Thus, we ensured that our participants have sufficient background knowledge to provide indepth insights into B2B web localization issues. The focus groups were tape-recorded and later transcribed and analyzed for themes around the elements of the proposed B2B web localization framework. Because the paper is dealing with web localization, a mix of domestic and international participants was deemed appropriate. Participants were instructed to provide feedback strictly applicable to B2B web sites rather than B2C web sites. Participants were reminded several times that the focus of the study is on $\mathrm{B} 2 \mathrm{~B}$ rather than $\mathrm{B} 2 \mathrm{C}$ to minimize the overlap between $\mathrm{B} 2 \mathrm{~B}$ and $\mathrm{B} 2 \mathrm{C}$.

\section{Results}

Each web site was analyzed on variables proposed in the framework and each variable was measured on a five-point bipolar scale. The aggregate analysis evaluates the B2B firm's general localization efforts on each variable in this study. The data from content analysis was analyzed by aggregate analysis and percentage frequency count to assess the degree to which the US companies are localizing their web content on their Korean web sites.

\section{Content Analysis Result for Context Localization}

The aggregate sample values for each of the Context Localization variables are shown in Table $6.1,6.2$ and 6.3 .

\section{Trust}

The overall results relating to 'Institution Based Trust features' show that companies have not accomplished a high degree of Context Localization as only 2 percent of sites had uniquely localized the depiction of Structural Safeguards, 6 percent had uniquely localized the depiction of Trust Generating Seals and none of the sites had localized Cooperative Norms on the Korean web pages.

In general, companies did a better job of localizing Process Based Trust features of their Korean web sites than the Institution Based Trust features. Companies did well on the Company Management variable where 42,22 and 4 percent were coded as "Different", "Very Different" and "Unique" respectively. Companies also did well on Company Recognition variable where 24, 26 and 4 percent were coded as "Different", "Very Different" and "Unique" respectively. Overall, about 30 percent of the companies coded had "Very Different" and "Unique" levels of localization. This is still not high but better than levels of localization shown on Institution Based Trust items.

\section{Relationship Specific Investments}

Our data analysis revealed that companies have done relatively poorly on the degree of localization 
with regard to Relationship-Specific Investments features for Context Localization. Based on the measures of the above variables, 80 percent of the companies' web sites had only "Standardized" or "Slightly Different" levels of localization, indicating that they have not put much effort into localizing this feature of their web sites.

\section{Communication}

The Community variable showed the most localization promise, with 50 percent of the companies coded as "Very Different" and "Unique". However, based on the measures of Contact Information and Advice variables, only about 10 percent of the companies had "Very Different" and "Unique" levels of localization, while 85 percent of the companies' web sites showed only "Standardized" or "Slightly Different" levels of localization.

Table 5. Rotated Component Matrix ${ }^{a}$

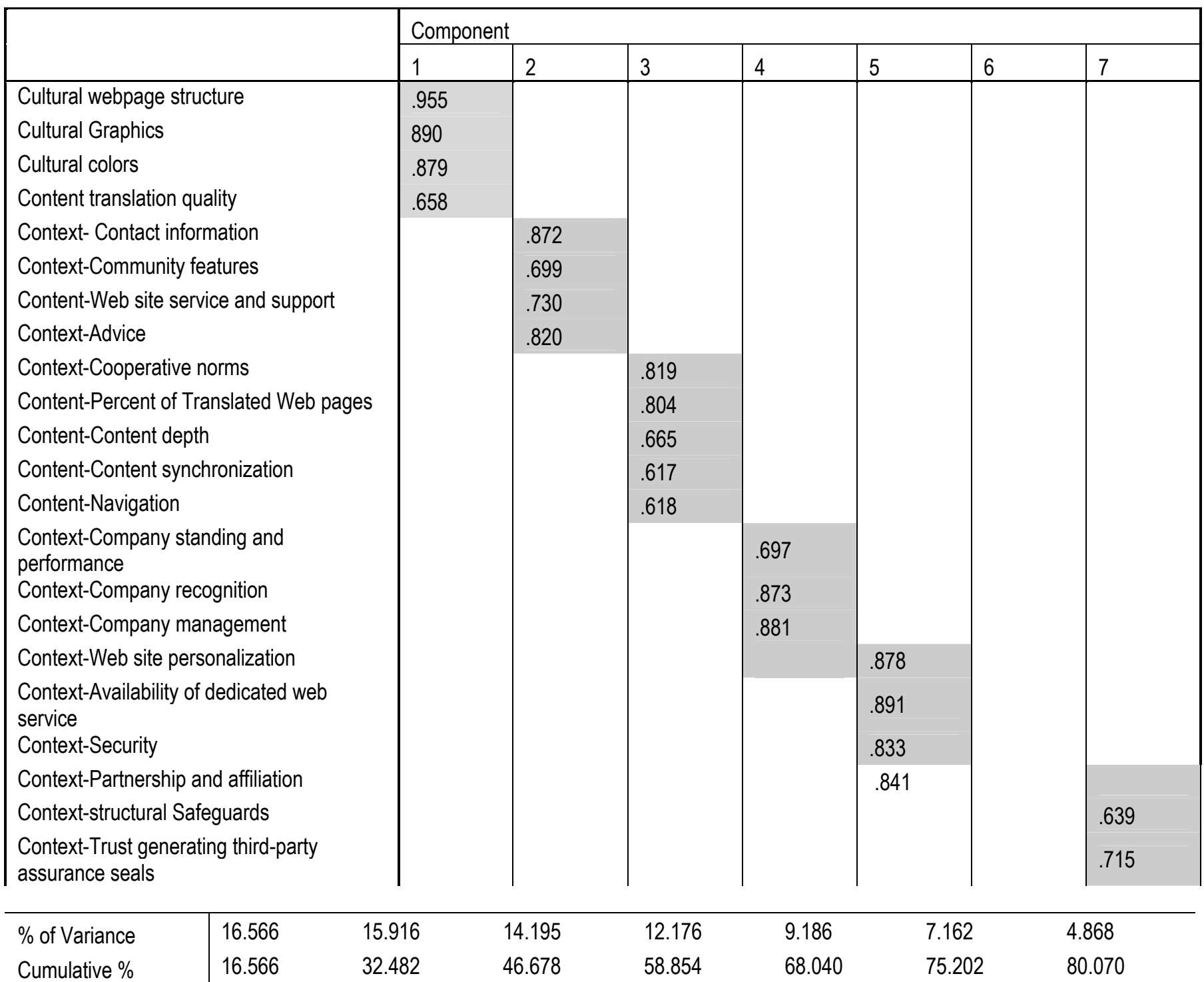

Extraction Method: Principal Component Analysis.

Rotation Method: Varimax with Kaiser Normalization.

a. Rotation converged in $\mathbf{1 7}$ iterations 
Table 6.1. Context Localization Count and Percentages: Trust features

\begin{tabular}{|c|c|c|}
\hline Category/Scale & Count & Percent \\
\hline \multicolumn{3}{|c|}{ Institution Based trust features } \\
\hline \multicolumn{3}{|c|}{ Structural Safeguards } \\
\hline Standardized & 25 & 50.0 \\
\hline Slightly Different & 12 & 24.0 \\
\hline Different & 7 & 14.0 \\
\hline Very Different & 5 & 10.0 \\
\hline Unique & 1 & 2.0 \\
\hline \multicolumn{3}{|l|}{ Cooperative Norms } \\
\hline Standardized & 21 & 42.0 \\
\hline Slightly Different & 13 & 26.0 \\
\hline Different & 14 & 28.0 \\
\hline Very Different & 2 & 4.0 \\
\hline Unique & 0 & .0 \\
\hline \multicolumn{3}{|c|}{ Trust Generating Third-Party Assurance Seals } \\
\hline Standardized & 37 & 74.0 \\
\hline Slightly Different & 3 & 6.0 \\
\hline Different & 4 & 8.0 \\
\hline Very Different & 3 & 6.0 \\
\hline Unique & 3 & 6.0 \\
\hline \multicolumn{3}{|c|}{ Process Based Trust features } \\
\hline \multicolumn{3}{|c|}{$\begin{array}{l}\text { Partnerships/Affiliations with Respected Organizations } \\
\text { (Industrial Associations) }\end{array}$} \\
\hline Standardized & 11 & 22.0 \\
\hline Slightly Different & 26 & 52.0 \\
\hline Different & 3 & 6.0 \\
\hline Very Different & 8 & 16.0 \\
\hline Unique & 2 & 4.0 \\
\hline \multicolumn{3}{|c|}{$\begin{array}{l}\text { Company Standing and } \\
\text { Performance }\end{array}$} \\
\hline Standardized & 3 & 6.0 \\
\hline Slightly Different & 22 & 44.0 \\
\hline Different & 12 & 24.0 \\
\hline Very Different & 8 & 16.0 \\
\hline Unique & 5 & 10.0 \\
\hline \multicolumn{3}{|l|}{ Company Management } \\
\hline Standardized & 2 & 4.0 \\
\hline Slightly Different & 14 & 28.0 \\
\hline Different & 21 & 42.0 \\
\hline Very Different & 11 & 22.0 \\
\hline Unique & 2 & 4.0 \\
\hline \multicolumn{3}{|l|}{ Company Recognition } \\
\hline Standardized & 5 & 10.0 \\
\hline Slightly Different & 18 & 36.0 \\
\hline Different & 12 & 24.0 \\
\hline Very Different & 13 & 26.0 \\
\hline Unique & 2 & 4.0 \\
\hline
\end{tabular}

\section{Content Analysis Results for Content Localization}

The aggregate values for each of the Content Localization variables are shown in Table 7.
Table 6.2. Context Localization Count and Percentages: Relationship Specific Investments

\begin{tabular}{|l|l|l|}
\hline Category/Scale & Count & Percent \\
\hline Web Site Personalization & & \\
\hline Standardized & 21 & 42.0 \\
\hline Slightly Different & 20 & 40.0 \\
\hline Different & 5 & 10.0 \\
\hline Very Different & 4 & 8.0 \\
\hline Unique & 0 & .0 \\
\hline $\begin{array}{l}\text { Availability of Dedicated Web } \\
\text { services }\end{array}$ & & \\
\hline Standardized & 33 & 66.0 \\
\hline Slightly Different & 11 & 22.0 \\
\hline Different & 5 & 10.0 \\
\hline Very Different & 1 & 2.0 \\
\hline Transactional Security & & \\
\hline Standardized & 26 & 52.0 \\
\hline Slightly Different & 10 & 20.0 \\
\hline Different & 11 & 22.0 \\
\hline Very Different & 2 & 4.0 \\
\hline Unique & 1 & 2.0 \\
\hline
\end{tabular}

Table 6.3. Context Localization Count and Percentages: Communication

\begin{tabular}{|l|l|l|}
\hline Category/Scale & Count & Percent \\
\hline Contact Information & & \\
\hline Standardized & 8 & 16.0 \\
\hline Slightly Different & 35 & 70.0 \\
\hline Different & 4 & 8.0 \\
\hline Very Different & 3 & 6.0 \\
\hline Unique & 0 & .0 \\
\hline Advice & & \\
\hline Standardized & 16 & 32.0 \\
\hline Slightly Different & 26 & 52.0 \\
\hline Different & 2 & 4.0 \\
\hline Very Different & 2 & 4.0 \\
\hline Unique & 4 & 8.0 \\
\hline Community features & & \\
\hline Standardized & 2 & 4.0 \\
\hline Slightly Different & 8 & 16.0 \\
\hline Different & 15 & 30.0 \\
\hline Very Different & 18 & 36.0 \\
\hline Unique & 7 & 14.0 \\
\hline
\end{tabular}

\section{Language Usage}

The percent of English language web pages translated to Korean was 70.9 percent on average with a median value of $73.2 \%$. Half of the web sites in the sample ( 25 web sites) had 95 percent or more of their English language pages available in Korean. This shows that US companies are in fact taking translation as an important way to localize the web content. 
Table 7. Content Localization Count and Percentages

\begin{tabular}{|c|c|c|}
\hline Category/Scale & Count & Percent \\
\hline \multicolumn{3}{|l|}{ Language Usage } \\
\hline $\begin{array}{l}\text { Percent of Korean Translated Web } \\
\text { Pages }\end{array}$ & NA & \\
\hline \multicolumn{3}{|l|}{ Content Depth } \\
\hline Basic store and contact information & 3 & 6.0 \\
\hline 1 or 2 sections translated in Korean & 18 & 36.0 \\
\hline 2 or 3 sections translated in Korean & 16 & 32.0 \\
\hline 4 or 5 sections translated in Korean & 10 & 20.0 \\
\hline All sections translated in Korean & 3 & 6.0 \\
\hline \multicolumn{3}{|l|}{ Currency, Navigation and Support } \\
\hline \multicolumn{3}{|l|}{ Content Synchronization } \\
\hline $\begin{array}{l}\text { Content is out of sync with English } \\
\text { content }\end{array}$ & 24.0 & \\
\hline Better sync with English pages & 1938.0 & \\
\hline $\begin{array}{l}\text { Much better sync with English } \\
\text { pages }\end{array}$ & 1632.0 & \\
\hline Good sync with English pages & 1224.0 & \\
\hline $\begin{array}{l}\text { Most Korean Content is in sync with } \\
\text { the English content }\end{array}$ & 12.0 & \\
\hline \multicolumn{3}{|l|}{ Navigation } \\
\hline Very Poor & 00.0 & \\
\hline Poor & 3 & 6.0 \\
\hline Neutral & 23 & 46.0 \\
\hline Good & 17 & 34.0 \\
\hline Very Good & 7 & 14.0 \\
\hline \multicolumn{3}{|l|}{ Web Site Service and Support } \\
\hline No online support & 1020.0 & \\
\hline
\end{tabular}

\begin{tabular}{|l|l|l|}
\hline $\begin{array}{l}\text { Support available but takes to } \\
\text { English Page }\end{array}$ & 2346.0 & \\
\hline Basic Support & 1428.0 & \\
\hline Equivalent to English Pages & 36.0 & \\
\hline Superior to English Pages & 0.0 & \\
\hline Category/Scale & Count & Percent \\
\hline Web Page Structure & & \\
\hline Standardized 32 & & 64.0 \\
\hline Slightly Different & 5 & 10.0 \\
\hline Different 4 & & 8.0 \\
\hline Very Different & 5 & 10.0 \\
\hline Unique 4 & & 8.0 \\
\hline Graphics & & \\
\hline Standardized 33 & & 66.0 \\
\hline Slightly Different & 6 & 12.0 \\
\hline Different 5 & & 10.0 \\
\hline Very Different & 4 & 8.0 \\
\hline Unique 2 & & 4.0 \\
\hline Colors & & \\
\hline Standardized 25 & & 50.0 \\
\hline Slightly Different & 12 & 24.0 \\
\hline Different 5 & & 10.0 \\
\hline Very Different & 4 & 8.0 \\
\hline Unique 4 & & 8.0 \\
\hline Translation Quality & & \\
\hline Very Poor & $\mathbf{0}$ & $\mathbf{0 . 0}$ \\
\hline Poor & $\mathbf{1 0}$ & $\mathbf{2 0 . 0}$ \\
\hline Neutral & $\mathbf{1 3}$ & $\mathbf{2 6 . 0}$ \\
\hline Good & $\mathbf{2 0}$ & $\mathbf{4 0 . 0}$ \\
\hline Very Good & $\mathbf{7}$ & $\mathbf{1 4 . 0}$ \\
\hline & & \\
\hline
\end{tabular}

However, a more in-depth analysis of Content Depth data revealed that only 26 percent of the companies had translated all or majority of their web site sections in Korean.

\section{Currency, Navigation and Support}

More than 24 percent of the companies' web sites had "good synchronization with English pages" as shown in Table 7. Thus, the content on the Korean web sites was updated and relevant compared to the English web pages. Companies did a better job on the Navigation aspects of their web sites with about 50 percent having "Good" to "Very Good" navigation qualities. However, analysis of the Web Site Service and Support data revealed that about 65 percent of the companies' web sites had "no online support" or "support available but takes the user to an English Page".

\section{Content Analysis Results for Cultural Customization}

The aggregate sample values for each of the Cultural Localization variables are shown in Table 8. The overall results show that companies have not accomplished a high degree of Cultural Customization. Based on the measures of Web Page Structure, Graphics, and Colors, about 75 percent of the companies' web sites had only "Standardized" or "Slightly Different" levels of localization. Thus, the majority of the web pages for Korean B2B markets were basically just translated versions of the English web pages with little to no cultural customization.

The companies did perform better in the area of Translation Quality compared to other cultural localization variables, wherein about 55 percent of the companies had "good" to "very good" translation quality. 
Thus, based on the overall analysis, it seems that the trend in terms of localization has primarily focused on translation of the content, with less attention to other measures of localization related with context, content and cultural localization. American company web sites showed the most localization in terms of translation quality, navigation, and depiction of community features. Items such as relationship-specific investments items, contact information and advice showed some of the least levels of localization.

\section{Focus Group Results}

From the focus group we tried to assess the degree of importance placed on various elements of our proposed B2B localization framework. We asked the focus group participants to evaluate how important various B2B web localization elements are in terms of determining their attitude and willingness to do business with the company. The information gathered from the focus group was a guided discussion, where the moderator suggested some ideas for the participants to discuss while other information emerged freely from the participants. For example, we asked participants to comment on the importance of trust building in B2B web sites. While participants provided specific information about trust and the reasons for its importance through this guided discussion, participants also provided information such as what they look for in a B2B web site as indicator of trust.

Trust emerged as an important factor when localizing B2B web sites. The focus group results showed that trust is important because of the high dollar transactions involved in a B2B context. Trust was seen as mechanism for lowering transactional risk and enhancing reassurance. Participants equated trust to company's brand recognitions, its country of origin, its reputation, transactional security and the implicit ideas of honesty and integrity. It was surprising to see that in a global context, trust was not only associated with the business partner but also the country of origin of the business. For example, a participant said: "For me trust $d$ epends on the co untry; if you $r$ com pany $i$ slocated in China...with a com munist regim e--there is some kind of uncertainty. It is issue of trust with regime not the com pany..." In the following paragraphs, we outline the various themes that emerged around important elements of B2B web localization.

\section{Institution Based Trust:}

A general feeling among participants was that Structural Safeguards will not be enough if the company behind the web site is not well known.
This shows that in the online B2B context, Process Based Trust needs to be established before Structural Safeguards can really help generate more trust. In words of a participant, "they ma y ha ve warranty o rgua rantee policy, but $i$ fyou d on't recognize the com pany at all... will they really follow through the policies..."

Regarding Cooperative Norms (Information on dispute resolution, arbitration, etc.) participants thought that in a global context, countries' rules and regulations triumph over company specified cooperative norms on the web site. Moreover, participants argued that in the case of high value B2B transactions having a local presence will alleviate more trust and security concerns than having Cooperative Norms specified on the web site. Thus, Cooperative Norms may not play as important role when localizing sites for international markets.

The role of Third Party Assurance Seals was seen instrumental in cases where the brand was not well known. A participant quoted "if company is ve rified by well-known third party that provides oversight for $B 2 B$ web sites - the $n$ you would $n$ ot be that apprehensive doing business with them..." The third party assurance should come from neutral and reputable organizations in the form of reports, audits, seals, credit ratings, financial ratings or even reports or verifications from well-known government agencies.

\section{Process Based Trust:}

When localizing B2B sites, the role of process based trust elements was seen as more crucial than structural safeguards and cooperative norms. Knowing a company's brand and its brand equity in terms of recognition, management, and performance was perceived as an important determinant of online trust. Company affiliations with well-known companies and also testimonials, customer reviews/feedback and case studies of well-known customers were recommended by participants as sources of trust in a global online context. For example, a participant stated, "if you know that Google trusts them then you can trust them too..." It was also emphasized that companies should showcase their relationships with recognized industry associations or bodies to generate trust. For example, a participant said, "If $l$ ' $m$ a pu rchasing manager fro $m$ aerosol company and they 're not a part of the CSPA ${ }^{3}$, they're done".

\footnotetext{
${ }^{3}$ The Consumer Specialty Products Association (CSPA) is a trade association
} 
Relationship-Specific Investments:

"..If you are doing business on the web, then secure payments a nd se curity of inform ation is a bare minimum...it is a deal breaker...it is expected..."

Transactional Security is seen as a bare minimum when localizing a B2B site for any country. Furthermore, in terms of Web Personalization and Dedicated Web Services the consensus was that such localization features perhaps may enhance the experience, transactional ease and save time for customers. According to participants, it is also important that the B2B customer be empowered to personalize the web page content to their needs and transactional demands. One participant noted, "if on a supplier web site yo u could log in and put yo ur purchase order ... and it would give you a status of where that order was in the manufacturing cycle that would be revol utionary". But one concern that emerged was the resistance to share private information to enable web personalization, as participants indicated mistrust of how the companies use their private data and expressed hacking concerns. Another important point put forward was that companies should personalize or use customer recommendation systems in a way that the customers do not feel as if they are being cajoled into buying.

\section{Communication:}

Communication-related localization features, like Contact Information and Online Help and Advice, were seen as more important in terms of substituting for lack of human contact than web personalization and customer recommendation features. Ability to connect with a real human being via real time chat, phone, and tech support were seen as important determinants for facilitating B2B commerce in a global context. Participants also noted information on key contacts relevant to a purchasing manager would help facilitate communication ease. For example, a participant stated, "if I'm a business to business, my web site should be tailored through the eyes of a purchasing person, what are the things I'm looking for?"

Furthermore, Community Features like wikis, blogs and forums were seen as less pertinent in the B2B commerce context than the B2C context. It was recommended that Community Feature's role could be primarily informational and related to some brand building rather than as a tool to facilitate the conduct or B2B commerce. Relative lack of interest, in the global B2B context, of community features was primarily because of lack of trust in public forums, and as one participant said "anybody $c$ an $w$ rite anything they want".

\section{Content Localization:}

Not having translated content was seen as a deal breaker. Lack of translated content was seen as not only as a communication barrier, but also a sign of lack of commitment to the local market. Participants also observed that if only few web pages are translated, then it shows the company is not really vested in the local market and it also shows disrespect to the local consumer. For example, the following quotes reveal that lack of translation or partial translation of web site can result in feelings like: "They don't care en ough to communicate with me in m y la nguage"; "I want to kno w what I am missing out on"; "What are they not telling me"; "Are they trying to hide something?"

Localized navigational tools were considered important to facilitate information search and as mechanisms to enhance browsing and save time. Furthermore, unlike B2C sites, the B2B sites need not be flashy or have many graphics, but be purpose driven and have updated and relevant content.

\section{Cultural customization:}

To participants, minor grammatical flaws were forgivable but lack of Translation Quality was a sign of poor professionalism and a reflection of poor overall product/service quality and organization wide disarray. Interestingly, participants were more forgiving of translation quality for small businesses compared to large fortune 500 companies. A participant said, "If it is a million dollar com pany it has to have a perfect web site".

In terms of culturally customizing the web site (graphics, colors, structure), the participants agreed that it is important to localize culturally when doing business globally. But they also mentioned that core brand personality should be kept standard and balanced with relevant cultural customization: "if you are going to do business globally the $n$ you need to take the tim e to do the research to $u$ nderstand the other cultures you a re $d$ ealing with". Furthermore, Culturally Customizing the site to the local market also served to participants as a cue that the company is more experienced and familiar with doing business in the country.

Overall, in terms of Cultural Customization in a B2B context, Translation Quality was seen as the most important element of localization.

\section{Best Practices}

For Context localization, Content localization, and Cultural customization, we identify several companies' Korean web sites as best practices which can serve as benchmark for multinational companies' future web site localization efforts. 


\section{Context Localization}

The partnership pages on the CISCO Korea site cover very detailed information on CISCO Korea partners. According to CISCO Korea partnership site, it categorizes partners as gold, silver, premier, and provides names, phone numbers, and web sites information of each partner. CISCO Korea web site provides information on detailed company profile related to company history and longevity, awards, reputable clients, and its successful cases of transactions. It has featured membership services such as blogs and member's site registration.

\section{Content Localization}

In the case of IBM Korea's web site, almost all sections from English pages are translated into Korean and show more specific and localized information for Korean customers. In addition, the content of the Korean web site is up-to-date, and the web site covers good navigation attributes such as adequate hyperlinks, FAQs, and on-line search help. There is very detailed contact information under IBM Korea site. The contact information includes email address, phone number, fax number, and local maintenance center and its map.

\section{Cultural Customization}

The web site structure of El du Pont de Nemours (DuPont) Korea is quite different from that of the Du Pont global company. Du Pont's global site is designed as a place for offering information in terms of industry and consumer offering, thus, subcategories of industry and consumers offering are located on the main page. The main page of the Du Pont global site is more information centric and uses less pictures and flashes. On the other hand, the main page of Du Pont Korea uses fewer texts, but uses more graphics and flashes. Du Pont Korea's main page is well structured, and sub-categories are not shown in the main page. Du Pont Korea's product names and concepts are precisely translated with appropriate words, and these words are easy to understand.

\section{Limitations and Future Research}

The focus of this paper has been to develop a framework of B2B web sites; however, the majority of the literature in the arena of standardization vs. localization of marketing strategy has focused on B2C rather than B2B. Therefore, the theoretical foundation of the framework suggested here is likely to be influenced by B2C studies and should be interpreted with caution. It is recommended that future research should cross-validate and test this proposed framework and its factor structure using confirmatory factor analysis.

Furthermore, the inherent limitation of the content analysis method used in this study is that it tells us what is there but does not tell us why a certain phenomenon exists. Therefore, the results of the content analysis should be interpreted with this in mind. Perhaps future studies can use experimental research design to test the importance of the proposed elements of the B2B web localization framework. We recommend that future studies also test the proposed B2B web localization framework by survey method. The survey of managerial perceptions of B2B web localization elements can help us better understand which localization elements might be considered important by practitioners.

While this study demonstrates how the framework can provide insight into the localization efforts for the Korean online B2B market, additional research is needed to validate this $\mathrm{B} 2 \mathrm{~B}$ web site localization framework in other markets. For example, are the major constructs identified in this study for measuring B2B web sites' localization the same in other cross-national settings? Is there a more "generic" framework that could encompass a wider spectrum of localization efforts? Future research can test the mutual exclusivity of the proposed B2B web localization dimensions and could empirically validate this framework in cross-national and crossindustry settings.

\section{Implications for Business Marketing Practice}

This research represents one of the first academic attempts to present a framework for measuring B2B web site localization, based on the literature review, qualitative exploration and empirical testing. The results provide insights into how well companies are targeting their B2B markets and what web localization elements $\mathrm{B} 2 \mathrm{~B}$ web sites need to emphasize.

The overall results show that U.S. companies have not accomplished a high degree of localization for B2B markets. The study results indicate that most U.S. companies focus primarily on the translation of web content from English to Korean to create web sites. For example, half of the sampled firms have $95 \%$ or more of their web sites translated into Korean. Companies have also made some progress in localizing their sites for Korean B2B markets in the following areas: Partnerships/Affiliations with Respected Organization (industrial associations); Company Standing and Performance; Company 
Management; Company recognition; Community Features; Navigation; and Translation Quality.

However, there are still many web design areas where localization efforts for B2B markets are not sufficiently high in quality. There is great potential for enhanced localization efforts in Context, Content, and Cultural Localization.

There is compelling data to suggest that culturally localizing a web site leads to better web site acceptance, greater purchase intentions, and better attitude toward a company's product or service (e.g., Singh and Pereira, 2005). However, the results presented in this study demonstrate that most organizations have not yet truly localized their B2B web sites to connect with their Korean online audiences. To effectively target Korean B2B markets online, companies should go beyond basic translation to provide a truly localized and culturally customized experience. The conceptual framework presented in this study provides useful information about the variables to consider in constructing a well-designed, highly localized web site.

Our objective was to present a framework that could assist in assessing the localization of business to business web sites. Our data analysis looked at various variables that could help companies achieve this objective. The items presented in this study have been validated via an exploratory factor analysis, wherein the unidimensionality of items was tested. Our data analysis indicates that the items load well on six factors, providing more support that this framework targets six specific areas (Institution Based Trust Features, Process Based Trust Features, Relationship-Specific Investments, Communication, Content Localization and Cultural Localization) that can assist in measuring web site localization. While it is true that globalization has brought us closer than ever to Mcluhan's (1964) idea of a global village, major differences across countries and regions exist and play a significant role in how consumers react to web site designs and content (Luna et al., 2002; Singh and Pereira, 2005). Therefore, this framework is vital to business seeking consumers globally. Using this framework should allow these businesses to modify their B2B web sites and include key areas that appeal to local consumers.

The focus groups allowed us to further validate the proposed framework and also provided unique business insights into degree of importance of various web features needed to enhance B2B web site localization. Brand Recognition and Company Ranking seemed to be the most important trust generating factors online, followed by Third Party Trust Seals, Partnerships/Affiliations and Structural Safeguards. Furthermore, according to participants brand recognition is driven by how public sources, press/media, and neutral third parties review the brand/company. Thus, it seems providing links to well-known neutral third parties that could lend credibility and recognition, may be important to drive brand recognition. In the words of a participant, "this is what $m$ akes Inte rnet different, that yo $u$ cannot implicitly tru st the we $b$ site, it has to be ab out the brand or company b ehind that web site and you have to be a ble to find more in dependent re search validating that they are st rong or g ood organization to do $b$ usiness with". Overall, using web features related to personalization were seen as a poor substitute for relationship development, which takes place via personal contact or face to face interaction. For example, a participant noted: "I do not form a relationship with an electronic code, I form a relationship with a person an $d$ that $p$ erson represents the company...the relatio nship comes from the hum an aspect". The web site is seen as a tool to facilitate B2B commerce and not a replacement for human contact and relationship. But communication tools like online help and chat were seen acceptable substitutes for the lack of face to face human contact. Another important element in terms of B2B localization was the translation quality of the web content. Focus groups also revealed that cultural customization seems to signal to consumers that a company understands local culture and local business environment.

Finally, the focus group revealed that there are certain elements of the proposed B2B localization framework that are not just important, but are critical for facilitating $\mathrm{B} 2 \mathrm{~B}$ online commerce. These elements included transactional security and availability of the web content which is in customer's native language.

\section{References}

Al-Badi, A. \& Naqvi, S. (2010), "A Conceptual Framework for Designing Localized

Business Web Sites.".Journal of Mana gement and Marketing Research . Available at: http://ww.aabri.com/manuscripts/09211.pdf

Al-Badi, A. \& Mayhew P. J. (2010), "A Framework for Designing Usable Localised Business Websites." Communications of the IBIMA .2010. Available at: http://www.ibimapublishing.com/journals/CIBIMA/ 2010/184405/184405.pdf

Anderson, J. \& Narus, J. A. (1990), "A Model of Distributor Firm and Manufacturer Firm Working Partnerships." Journal of Marketing . Vol. 54 (January), 42-58.

Anderson, E. \& Weitz, B. (1989). "Determinants of Continuity in Conventional Industrial Channel Dyads." Marketing Science. Vol. 8 (4), 310-323. 
Angeles, R. \& Nath, R. (2007). "Business-to-Business E-procurement: Success Factors and Challenges to Implementation." Supply Chain Man agement. Vol. 12 (2), 104-115.

Baack, D. \& Singh, N. (2007). "Culture and Web Communications." Journal of Business Research. Vol. 60 (3), 181-188.

Barber, W. \& Badre, A. (1998). "Culturability: The Merging of Culture and Usability. Human Factors and the Web (4th Conference), Retrieved January 25, 2012, Available at: http://zing.ncsl.nist.gov/hfweb/att4/proceedings/b arber

Bart, Y., Shankar, V., Sultan, F., \& Urban, G.L. (2005). "Are the Drivers and Role of Online Trust the Same for All web Sites and Consumers? A Large Scale Exploratory Empirical Study." Journal of Marketing. Vol. 69 (October), 133-152.

Becker, S. A. \& Crespo, F. (2001), "A Multicultural Perspective on Digital Government Usability." In Proceedings of $\mathrm{HCl}$ New Orleans, Louisiana, 773 777.

Becker, S. A. (2002). "An Exploratory Study on Web Usability and the Internationalization of U.S. Ebusiness." Journal of Electronic C ommerce Research. Vol. 3 (4), 265-278.

Berthon, P., Pitt, L., Berthon, JP., Campbell, C.,\&Thwaites, D. (2008). "E-Relationships for eReadiness: Culture and Corruption in International e-B2B." Industrial Marketing Mangement. Vol. 37 (1), 83-91.

Boudreau, M. \& Watson, R. T. (2006). "Internet Advertising Strategy Alignment." Internet Research. 16 (1), 23-38.

Chakraborty, G., Lala, V., \& Warren, D. (2003). "What Do Customers Consider Important in B2B websites?" Journal of Advertising Research . Vol. 43, 50-61

Chen, M., Chen, A. N., Shao, B. M. (2003), "The Implications and Impacts of Web Services to Electronic Commerce Research Practices." Journal of Electronic Commerce Research. Vol. 4 (4).128-39.

Cunningham, M. \& Homse, E. (1986). "Controlling the Marketing-Purchasing Interface: Resource Development and Organizational Implications." Industrial Marketing \& Purchasing. Vol. I (2), 325.

Cyr, D. \& Trevor-Smith, H. (2004). "Localization of Web Design: An Empirical Comparison of German, Japanese and United Stats Web Site Characteristics." Journal of the American Society for In formation Science and Technology . Vol. 55 (13), 1199-1208.

Cyr, D. \& Lew, R. (2003). "Emerging Challenges in the Software Localization Industry." Th underbird
International Business Review. Vol. 45 (3), 337358.

Doney, P. M. and J. P. Cannon, (1997). "An examination of the Nature of Trust in Buyer-seller Relationships." Journal of Marketin. Vol. 61 (1) 35-51.

Dou, W., Nielsen, U. O, \& Tan, C. M. (2002). "Using Corporate Websites for Export Marketing." Journal of Advertising Research. Vol. 42, 105115

Dwyer, F. R., Schurr, P. H., \& Oh, S. (1987). "Developing Buyer-Seller Relationships." Journal of Marketing. Vol. 51 (2), 11-27.

Esselink, Bert (2000). "A Practical Guide to Software Localization." John Benjamins. Philadelphia.

E-Stats-Untitled (2009), "US Census Bureau: EStats", Available at: http://www.census.gov/econ/estats/2007/2007rep ortfinal.pdf or www.census.gov/estats

Ferranti, M. (1999). "From Global to Local." InfoWorld. Vol. 21 (41), 36-37.

Ganesan, S. (1994). "Determinants of Long-term Orientation in Buyer-Seller Relationships." Journal of Marketing. Vol. 58 (2), 1-19.

Garbarino, E. \& Johnson, M. (1999). "The Different Roles of Satisfaction, Trust, and Commitment in Customer Relationships. Journal of Marketing . Vol. 63 (2), 70-87.

Hair, J.; Anderson, R.; Tatham, R. and Black, W. (1998), Multivariate Data Analysis, $5^{\text {th }}$ ed. Prentice Hall, Upper Saddle River, NJ.

Hermeking, M. (2005). "Culture and Internet Consumption: Contributions from Cross-Cultural Marketing and Advertising Research." Journal of computer Mediated Co mmunication. Vol. 11 (1), article 10, Available at:

http://jcmc.indiana.edu/vol11/issue1/hermeking.html

Hill, J. S. \&Still, R. R. (1984). "Adapting Products to LDC Tastes." Harvard Business Review . Vol. 62 (March/April), 92-101

Hurley, A. E., Scandura, T. A., Schriesheim, C. A., Brannick, M. T., Seers, A., Vandenberg, R. J., et al. (1997). Exploratory and Confirmatory Factor Analysis: Guidelines, Issues, and Alternatives." Journal of Organizational Behavior. Vol. 18, 667683

Internetworldstats.com (2011).Top Ten Languages Used in theWeb http://www.internetworldstats.com

Jain, S.C. (1989). "Standardization of International Strategy: Some Research Hypotheses." Journal of Marketing. Vol. 53 (January), 70-9

Jarvenpaa, S. L., Tractinsky, N., Saarinen, L., \& Vitale, M. (1999). "Consumer Trust in an Internet Store: Cross Cultural Validation." Journal of Computer Mediated Communication. Vol. 5 (2), Available at: http://jcmc.indiana.edu/vol5/issue2/jarvnpaa.html 
Johanson, J., \& Vahlne, Jan-E. (2009). The Uppsala Internationalization Process Model Revisited: From Liability of Foreignness to Liability of Outsidership." Journal of International Business

Stud ies. Vol. 40, 1411-31

Knight, G. A. \& Cavusgil, T. S. (1996). "The Born Global Firm: A Challenge to Traditional Internationalization Theory, in Cavusgil and Madsen (eds.)" Advances in In ternational Marke ting, JAI Press

Kajan, E. \& Stoimenov, L. (2005).Toward an Ontology-driven Architectural Framework for B2B Association for Computing Machinery." Communications of the ACM. Vol. 8 (12), 60-66.

Kassarjian, H. (1977). "Content Analysis in Consumer Research." Journal of Co nsumer Research. Vol. 4 (June), 8-18.

Lancaster, A. \& Lages, L.F. (2006). "The Relationship Between and Buyer and A B2B E-Marketplace: Cooperation Determinants In An Electronic Market Context." Industrial Marketing Management. Vol. 35, 774-789.

Lawson-Body, A. \& Keefe, T. P. (2006). "Interorganizational Relationships in the context of SMEs' B2B E-Commerce." Journal of Electronic Commerce in Organizations. Vol. 4 (4), 1-28.

Lichtenthal, J. D., \& Eliza, S. (2003). "Internet Integration In Business Marketing Tactics." Industrial Marketing Management. Vol. 32 (1), 313

Legner, C. \& Vogel, T. (2008). "Leveraging Web Services for Implementing Vertical Industry Standards: A Model for Service-based Interoperability." Electronic Markets. Vol. 18 (1), 39-52.

Levitt, M. (1983). "The Globalization of Markets." Harvard Business Review. Vol. 61 (3), 92 -103.

Lord, K. R., \& Collins, A. F. (2002). "Supplier Webpage design and organizational buyer preferences." Journal of Business \& Industrial Marketing. Vol. 17, 139-150.

Luna, D., Peracchio, L. A.,\& de Juan, M. D. (2002). "Cross-Cultural and Cognitive Aspects of Web Site Navigation." Journal of the Aca demy of Marketing Science. Vol. 30 (4), 397-410.

Mayer-Guell, A. M. (2001). "Business-to-Business Electronic Commerce." Management $C$ ommunication Quarterly. Vol.14 (4), 644-652.

Mohr, J. \&Nevin, J. (1990). "Communication Strategies in Marketing Channels: A Theoretical Perspective." Journal of Marketing. Vol. 54 (4), 36-51.

Moorman, C., Deshpandé, R., \& Zaltman, G. (1993). "Factors Affecting Trust in Market Research Relationships." Journal of Marketing. Vol. 57 (1), 81-101.
Morgan (1996). "Focus Groups." Annual Review of Sociology, Vol. 22 (1), 129-153

Morgan, R. \& Hunt, S. (1994). "The CommitmentTrust Theory of Relationship Marketing." Journal of Marketing. Vol. 58 (3), 20-38.

Nantel, J. \& Glaser, E. (2008). "The Impact of Language and Culture on Perceived Website Usability." Journal of Engineering and Technology Management. Vol. 25, 112-122.

Nielsen, J. \& E. del Galdo, (1996).International User Interfaces, J. Nielsen and E. del Galdo (eds.), John Wiley and Sons, New York, NY.

Palmatier, R., Dant, R., Grewal, D., \& Evans, K. (2006). "Factors Influencing the Effectiveness of Relationship Marketing: A Meta-Analysis." Journal of Marketing. Vol. 70 (4), 136-153.

Pavlou, P. A. (2000), "Institution-based Trust in Interorganizational Exchange Relationships: The Role of Online B2B Marketplaces on Trust Formation." Journal of Stra tegic Inform ation Systems. Vol. 11 (3-4), 215-243.

Pavlou, P. A. \& Gefen, D. 2004. "Building Effective Online Marketplaces with Institution-Based Trust." Information Syst ems Research. Vol. 15 (1), 3760.

Ratnasingam, P. \& Phan, D. (2003). "Trading Partner Trust in B2B E-commerce: A Case Study." Information System s Management. Vol. 20 (3), 39-50.

Ratnasingam, P. (2007). "A risk-control Framework for E-marketplace Participation: The Findings of Seven Cases." Information Manag ement \& Computer Security. Vol. 15 (2),149-66.

Samiee, S. (2008). "Global Marketing Effectiveness Via Alliances and Electronic Commerce In Business-To-Business Markets." Industria I Marketing Management. Vol. 37 (1), 3-8.

Samiee, S. \& Roth, K. (1992). "The Influence of Global Marketing Standardization on Performance." Journal of Marketing Vol. 56 (April), 1-17

Samiee, S. \& Walters, P. (2006). "Supplier and Customer Exchange in International Industrial Markets: An Integrative Perspective." Industrial Marketing Management. Vol. 35, 589-599.

Singh, N. (2012).Localization Strategies for Global eBusiness. Cambridge University Press.

Singh, N. \& Boughton, P. (2005). "Measuring Web Site Globalization: A Cross-Sectional country and Industry Level Analysis." Journal of Web Site Promotion. Vol. 1 (3), 3-20.

Singh, N., Fassott, G., Chao, M., \& Hoffmann, J. (2006). "Understanding International Web Site Usage: A Cross-National Study of German, Brazilian, and Taiwanese Online Consumers." International Marketing Review. Vol. 23 (1), 8398. 
Singh, N. \& Matsuo, H. (2004). "Measuring Cultural Adaptation on the Web: A content analytic study of U.S. and Japanese Websites." Journal of Business Research. Vol. 57 (8), 864-872.

Singh, N. \& Pereira, A. (2005) The Culturally Customized Web Site: Customizing Web Sites for the Globa I Marketplace, Elsevier ButterworthHeinemann: Burlington, MA.

Singh, N., Toy, D. R., \& Wright, R. K. (2009). "A Diagnostic Framework For Measuring Web-Site Localization." Thunderbird Interna tional Business Review. Vol. 51 (3), 281-295.

Singh, N., Zhao, H., \& Hu, X. (2003). "Cultural Adaptation On The Web: A Study of American Companies' Domestic And Chinese Websites." Journal of Global In formation Manage ment. Vol. 11 (3), 63-81.

Singh, N., Zhao, H., \& Hu, X. (2005). "Analyzing the Cultural content of Web Sites: A Cross-National comparison of China, India, Japan, and US." International Marketing Review. Vol. 22 (2), 129146.

Son, J. Y., Tu, L., \& Benbasat, I. (2006). "A Descriptive Content Analysis of Trust-Building Measures in B2B Electronic Marketplaces." Communication of the Association for In formation Systems,

Tixier, M. (2005). Globalization and Localization of Contents: Evolution of Major Internet Sites Across Sectors of Industry. Thunderbird Inte rnational Business Review. Vol. 47 (1), 15-48.

Tyler, K., Stanley, E., \& Brady, A. (2006). "Relationship Development in a Multinational Utilities Network." The Journal of Services Marketing. Vol. 20 (5), 333-345.

Usunier, J., Roulin, N., \& Ivens, B. S. (2009). Cultural, National, and Industry-level Differences in B2B Web Site Design and Content." International Journal of Electronic Comm erce. Vol. 14 (2), 4187.

Usunier, Jean-Claude, \& Roulin, N. (2010). The Influence of High- and Low-Context Communication Styles on the Design, Content, And Language Of Business-To-Business Web Sites." The Journal of Business Communication." Vol. 47 (2), 189-227

Wallace, S. \& Yu, H.C. (2009). "The Effect of Culture on Usability: Comparing the Perceptions and Performance of Taiwanese and North American MP3 Player Users." Journal of Usability Studies . Vol. 4 (3), 136-146.

Wang, S. \& Archer, N. (2004). "Supporting Collaboration in Business-to-business Electronic Marketplaces". Infor mation Systems and eBusiness Management. Vol. 2 (2-3), 269-286.
Wilson, S. G., \& Abel, I. (2002). "So You Want To Get Involved In E-Commerce." Industrial Marketing Management. Vol. 31, 85-94

Williamson, O.E. (1975). Market and Hierarchies: Analysis and Antitrust Implications. NY: The Free Press.

Wind, Y. (1986). "The Myth of Globalization." Journal of Consumer Marketin. Vol. 3 (2), 23-26.

Zucker, L. G. (1986). "Production of Trust: Institutional Sources of Economic Structure, 1840-1920, in Research in Organization Behavior, B.M. Staw and L.L. Cummings (eds), Greenwich, CT: Jai Press, pp. 53-111. 